\title{
Forage Yield and Quality of Dryland Grasses and Legumes
}

\author{
LARRY M. WHITE AND J. ROSS WIGHT
}

\begin{abstract}
A 7-year study was conducted on forage yield, digestibility, and crude protein of 7 species of grass, 3 cultivars of alfalfa, and cicer milkvetch at Sidney, Mont., from 1975 through 1981. Forage quality was inversely proportional with forage yield. Crude protein concentration of legumes and grasses decreased 0.8 and 1.25 percentage units, respectively, while dry matter digestibility decreased 1.5 to 2.3 percentage units per every $1,000 \mathrm{~kg} / \mathrm{ha}$ increase in forage yield. Meadow bromegrass and reed canarygrass produced the least forage from the second through seventh years of the study. Neither forage yield nor quality differed among the 3 creepingrooted alfalfas: 'Rambler', 'Drylander', and 'Orenberg', Russian wildrye, Altai wildrye, and green needlegrass produced the most forage during the 1980 drought, and the alfalfas, pubescent wheatgrass, and meadow bromegrass produced the least. Cicer milkvetch and reed canarygrass died during the 1980 drought. Forage digestibility of the alfalfas was 5 to 6 percentage units higher than that of the grasses, and the alfalfas also produced more digestible forage per unit of land. The crude protein concentration of alfalfas was almost twice that in grasses, and alfalfa produced almost twice as much crude protein per unit of land ( $\mathrm{kg} / \mathrm{ha})$.
\end{abstract}

In the evaluation of forage species and cultivars for livestock production, forage quality, as well as quantity, should be considered. If forages are used for maintenance of mature cows, maximum forage yield of each species is most important if digestibility is $50 \%$ or greater. However, if forages are used for growth of heifers or steers, or for additional energy for cows just before or after they calve, then high forage quality may be more important than forage yield.

Reports of 2 studies in the northern Great Plains contained data on both forage yield and dry matter digestibility (DMD) of major dryland forage species, but for only 1 or 2 years after establishment (Lawrence 1978, White and Wight 1981). Kilcher and Heinrichs (1974) and Kilcher (1980) showed that forages under semiarid conditions must be evaluated over a period of at least 5 years, excluding the first year after establishment, to determine their relative ranking.

Our objective was to determine forage yield, DMD, digestibleforage yield, crude protein (CP) concentration, and CP yield of 7 grass species, 3 cultivars of alfalfa, and cicer milkvetch over a 7-year period (1975-1981) when grasses were harvested at anthesis and legumes at $10 \%$ bloom.

\section{Materials and Methods}

The study site was on a glaciated plain $4 \mathrm{~km}$ northwest of Sidney, Mont., on a sandy range site (fine-loamy, mixed Typic Argiborolls) that normally receives $346 \mathrm{~mm}$ of precipitation yearly. The native vegetation (blue grama-threadleaf sedge-needleandthread (Bouteloua gracilis-Carex filifolia-Stipa comata) faciation of the mixed prairie) was removed with a rototiller, and the site was summer-fallowed for 2 years before seeding. The following legumes and grasses were seeded in a $12-\mathrm{m}$ rows spaced $50 \mathrm{~cm}$ apart during late May and early June of 1974:

The authors are range scientists, USDA-ARS, Southern Plains Range Research Station, 2000-18th St., Woodward, OK 73801, and Northwest Watershed Research Center, Suite 116, 1175 South Orchard Drive, Boise, Ida. 83705.

This study is a contribution from USDA-ARS, in cooperation with Montana Agr.

Exp. Sta., Sidney. Journal Series No. 1379

Manuscript received April 17, 1983.

Legumes

'Rambler', 'Drylander', and

'Orenberg' alfalfa

'Lutana' cicer milkvetch

Grasses

'Nordan' crested wheatgrass

'Luna' pubescent wheatgrass

'Regar' meadow bromegrass

'Prairieland' Altai wildrye

'Mayak' Russian wildrye

'Sidney sel.' reed canarygrass

'Lodorm' green needlegrass

\section{Medicago sativa subsp. varia (Martyn) Arc. Astragalus cicer L.}

Agropyron desertorum (Fisch. ex Link) Schult.

Agropyron intermedium var. trichophorum (Link) Halac.

Bromus biebersteinii Roem. \& Schult.

Elymus angustus Trin.

Psathyrostachys junceus

(Fisch.) Nevski (Dewey and

Hsiao 1983)

Phlaris arundinacea $\mathrm{L}$.

Stipa viridula Trin.

The 6- $X 12-\mathrm{m}$ plots were replicated 4 times in a completely randomized design. Specific details of the study site were previously described by White and Wight (1981). They reported on seasonal forage yield and DMD of the above-identified species sampled 7 and 11 times at progressive growth stages in 1975 and 1976, respectively, the first and second years after establishment. This paper will report on the forage yield and quality at anthesis or at $10 \%$ bloom of those same species from 1975 through 1981.

Forage from a $10-\mathrm{m}$ row was harvested to a $5-\mathrm{cm}$ stubble height at anthesis in all years except 1980 . A drought in 1980 would have prevented all species from reaching anthesis, and they were harvested on 2 June. Plant material was prepared for subsequent analysis by drying at $70^{\circ} \mathrm{C}$ and grinding to pass through a $1-\mathrm{mm}$ screen. In vitro DMD was determined by a modification of the Tilley and Terry two-stage method and data were converted to estimated in vivo DMD as described by White and Wight (1981). The 1977 forage samples were inadvertently discarded before in vitro DMD was determined. Nitrogen in the 1975 through 1977 forage samples was determined according to the procedure described by Schuman et al. (1973) after the forage was digested on a block digestor, and nitrogen in the 1978 through 1981 forage samples was determined by the macro-Kjeldahl method. Nitrogen concentration was multipled by 6.25 to estimate $C P$. Daily precipitation was measured at the site from April through October in a standard $20-\mathrm{cm}$ diameter rain gage. Precipitation data from November through March were obtained from the official weather station $4 \mathrm{~km}$ away.

Maximum and minimum daily air shelter temperatures were also measured at the official weather station. Daily mean temperatures above $3,5,7,9$, and $11^{\circ} \mathrm{C}$ threshold were accumulated from the first of February each year until anthesis of each species to calculated degree days required. In order to determine which threshold temperature most accurately predicted anthesis, degree days were normalized by a method previously reported by White (1979). The average degree days found for each species over the 5 or 6 years was used to determine which calendar date it would have predicted anthesis. The differences between predicted and actual anthesis 
dates with 51 observations was analyzed to determine which threshold temperature produced the lowest standard deviation in days.

A combined species-by-year analysis of variance was performed on forage yield, DMD, digestible-forage yield, CP concentration, and CP yield for the last 6 years of the study. Those analyses indicated a highly significant interaction among years and species; therefore, one-way analysis of variance was performed on data for each year and accumulated yield from 1976 through 1981. The cluster analysis method of Scott and Knott (1974) was used each year to separate treatment means into nonsignificant $(P=0.05)$ groups to illustrate differences among groups of species. All mean differences discussed in this paper are significant $(P<0.05)$ unless otherwise stated.

\section{Results and Discussion}

\section{Precipitation}

Precipitation during October through May 1974-75, 1975-76, 1977-78, and $1978-79$ was $8,31,51$, and $8 \%$ above the 30 -year average, respectively, and during that period in 1976-77, 1979-80, and $1980-81$ was 40,60 , and $18 \%$ below the 30-year average, respectively. Precipitation during the critical months (April-May) was 40,23 , and $79 \%$ above the 30 -year average during 1975,1976 , and 1978 and $62,7,81$, and $41 \%$ below the 30 -year average during $1977,1979,1980$, and 1981 , respectively, with a serious drought in 1980.

\section{Anthesis or $10 \%$ Bloom}

Russian wildrye, and meadow bromegrass were among the first species to reach anthesis; and crested wheatgrass, Altai wildrye, and pubescent wheatgrass were the last (Table 1). The date each species reached anthesis or $10 \%$ bloom varied by year and species and had a standard deviation of \pm 9.2 days from each species mean data. Threshold temperatures of $3,5,7,9$, and $11^{\circ} \mathrm{C}$ predicted anthesis within a standard deviation of $\pm 4.5,3.9,3.4,3.2$, and 3.4 days, respectively, for all species except alfalfas in 1981. Apparently, lack of rain until late May delayed the alfalfas from reaching $10 \%$ bloom by 14 days beyond the predicted date. It is not known why the best threshold temperature for these 11 species is 6 degrees higher than that found by White (1979) for 53 species at this same location.

\section{Forage Yield}

Alfalfas and pubescent wheatgrass produced their maximum forage yield in 1975, the first year establishment (Table 1). Other investigators have also found that pubescent wheatgrass (Whitman et al. 1961, Dubbs 1966) and alfalfa (Whitman et al. 1962) produced their maximum forage yield the first year after seeding. Altai wildrye, green needlegrass, Russian wildrye, crested wheatgrass, and meadow bromegrass produced their maximum forage yield in 1976, the second year after establishment.

Available $\mathbf{N}$ released from 2 years of summer fallowing prior to seeding may account for part of the increased forage production the first 2 or 3 years. Black and Wight (1979) reported that roots in this same native range site before it was plowed and seeded contained $181 \mathrm{~kg} \mathrm{~N} / \mathrm{ha}$ and the soil $9 \mathrm{~kg} \mathrm{~N} / \mathrm{ha}$ as $\mathrm{NO}_{3}-\mathrm{N}$. Assuming that it would require 3 to 4 years for the roots to decay releasing their $\mathbf{N}$, then 2 years of summer fallowing plus the establishment year would have released 135 to $180 \mathrm{~kg} \mathrm{~N} /$ ha which would have been available to the plants in 1975 and 1976.

The alfalfas, wheatgrass, and cicer milkvetch produced the highest forage yield of any species in 1975, and the wildryes produced the lowest (Table 1). The low forage yield by Russian and Altai wildryes was due to the low production of floral (reproductive) tillers during 1975, whereas the wheatgrasses produced nearly $100 \%$ floral tillers. Meadow bromegrass and reed canarygrass produced the lowest forage yield during the study.

The 1980 growing season provided an opportunity to observe the forage species under drought conditions. Green needlegrass, Russian wildrye, and Altai wildrye produced more forage than other species in 1980, but the quantity was still only 23 to $25 \%$ of the average that was produced in the previous 3 years. Meadow bromegrass, crested wheatgrass, and pubescent wheatgrass produced only 21,11 , and $5 \%$, respectively, of the average that was produced in the previous 3 years. Because of the drought, alfalfas, cicer milkvetch, and reed canarygrass produced no forage by early June 1980, and the latter two died. Russian wildrye and crested wheatgrass produced the most forage after the 1980 drought.

During the last 6 years, the average forage yield for wildryes, green needlegrass, alfalfas, wheatgrasses, and cicer milkvetch were nearly equal, but meadow brome and reed canarygrass produced significantly less than the other forages. The average forage yield of

Table 1. Average anthesis date, degree days (threshold $9^{\circ} \mathrm{C}$ ), and forage yield of grasses and legumes when harvested at anthesis or at $10 \%$ bloom each year for 7 years near Sidney, Montana.

\begin{tabular}{|c|c|c|c|c|c|c|c|c|c|c|}
\hline \multirow[b]{2}{*}{ Species/cultivars } & \multicolumn{2}{|c|}{ Anthesis } & \multicolumn{8}{|c|}{ Forage yield } \\
\hline & $\begin{array}{c}\text { Julian } \\
\text { date }\end{array}$ & $\begin{array}{c}\text { Degree } \\
\text { days }\end{array}$ & 1975 & 1976 & 1977 & 1978 & 1979 & 1980 & 1981 & $\begin{array}{l}\text { Avg. } \\
1976-81\end{array}$ \\
\hline \multicolumn{11}{|c|}{$\ldots \mathrm{Mg} / \mathrm{ha} \ldots$} \\
\hline \multicolumn{11}{|l|}{ Legumes } \\
\hline Drylander alfalfa & 165 & 290 & $3.4 \mathrm{a} \dagger$ & $3.0 \mathrm{a}$ & $1.0 \mathrm{~b}$ & $3.2 \mathrm{a}$ & $1.2 \mathrm{c}$ & $0.0 \mathrm{c}$ & $0.9 b$ & $1.6 \mathrm{a}$ \\
\hline Orenberg alfalfa & 165 & 290 & $3.3 \mathrm{a}$ & $2.9 \mathrm{a}$ & $1.6 \mathrm{a}$ & $2.6 \mathrm{~b}$ & $1.2 \mathrm{c}$ & $0.0 \mathrm{c}$ & $0.9 \mathrm{~b}$ & $1.5 \mathrm{a}$ \\
\hline Rambler alfalfa & 165 & 290 & $4.1 \mathrm{a}$ & $2.9 \mathrm{a}$ & $1.0 \mathrm{~b}$ & $3.0 \mathrm{a}$ & $1.0 \mathrm{c}$ & $0.0 \mathrm{c}$ & $0.7 \mathrm{~b}$ & $1.4 \mathrm{a}$ \\
\hline Cicer milkvetch & 169 & 350 & $2.6 a$ & $2.0 \mathrm{~b}$ & $1.0 \mathrm{~b}$ & $3.1 \mathrm{a}$ & $1.9 \mathrm{a}$ & $0.0 c$ & $0.0 \mathrm{c}$ & $1.3 \mathrm{a}$ \\
\hline \multicolumn{11}{|l|}{ Grasses } \\
\hline Altai wildrye & 174 & 400 & $0.4 b$ & $3.8 \mathrm{a}$ & $1.2 \mathrm{~b}$ & $2.6 \mathrm{~b}$ & $1.4 \mathrm{~b}$ & $0.4 a$ & $0.8 b$ & $1.7 \mathrm{a}$ \\
\hline Russian wildrye & 160 & 270 & $0.2 b$ & $3.4 a$ & $1.5 \mathrm{a}$ & $2.1 \mathrm{c}$ & $0.9 \mathrm{c}$ & $0.4 a$ & $1.4 \mathrm{a}$ & $1.6 \mathrm{a}$ \\
\hline Crested wheatgrass & 173 & 400 & $2.8 \mathrm{a}$ & $3.3 a$ & $1.8 \mathrm{a}$ & $2.1 \mathrm{c}$ & $1.1 \mathrm{c}$ & $0.2 b$ & $1.2 \mathrm{a}^{\circ}$ & $1.6 \mathrm{a}$ \\
\hline Green needlegrass & 163 & 300 & $1.2 \mathrm{~b}$ & $3.1 \mathrm{a}$ & $0.8 b$ & $3.1 \mathrm{a}$ & $0.9 c$ & $0.4 a$ & $0.9 \mathrm{~b}$ & $1.5 \mathrm{a}$ \\
\hline Pubescent wheatgrass & 180 & 470 & $3.5 \mathrm{a}$ & $3.0 \mathrm{a}$ & $1.6 \mathrm{a}$ & $2.6 \mathrm{~b}$ & $1.0 c$ & $0.1 \mathrm{c}$ & $0.6 b$ & $1.5 \mathrm{a}$ \\
\hline Meadow bromegrass & 160 & 260 & $1.2 \mathrm{~b}$ & $2.2 \mathrm{~b}$ & $0.9 b$ & $2.0 \mathrm{c}$ & $0.7 \mathrm{~d}$ & $0.2 \mathrm{~b}$ & $0.9 \mathrm{~b}$ & $1.2 \mathrm{~b}$ \\
\hline Reed canarygrass & 164 & 290 & $1.1 \mathrm{~b}$ & $1.6 \mathrm{~b}$ & $1.1 \mathrm{~b}$ & $1.9 \mathrm{c}$ & $0.5 \mathrm{~d}$ & $0.0 \mathrm{c}$ & $0.0 \mathrm{c}$ & $0.9 \mathrm{c}$ \\
\hline Average & - & - & 2.2 & 2.8 & 1.2 & 2.6 & 1.1 & 0.2 & 0.8 & 1.4 \\
\hline$F$ test & - & - & $* *$ & $* *$ & $*$ & $* *$ & $* *$ & $* *$ & $* *$ & $* *$ \\
\hline SE & $9.2 \ddagger$ & $3.2 \ddagger$ & 0.4 & 0.2 & 0.2 & 0.2 & 0.1 & 0.1 & 0.1 & 0.1 \\
\hline
\end{tabular}

†Treatment means followed by the same letter within a column are not significantly $(P=0.05)$ different from each other $(S c 0 t t$ and $\mathrm{Knott}, 1974)$.

$¥$ Standard deviation in days.

* Significant $(P<0.05)$, or highly significant $(P<0.01)$ differences among species that year. 
Table 2. Estimated in vivo DMD of grasses and legumes harvested at anthesis or at $10 \%$ bloom for 6 years near Sidney, Montana.

\begin{tabular}{|c|c|c|c|c|c|c|c|c|}
\hline \multirow[b]{2}{*}{ Species/cultivars } & \multicolumn{8}{|c|}{ DMD } \\
\hline & 1975 & 1976 & 1977 & 1978 & 1979 & 1980 & 1981 & $\begin{array}{l}\text { Avg. } \\
\text { 1976-81 }\end{array}$ \\
\hline $\begin{array}{l}\text { Legumes } \\
\text { Rambler alfalfa } \\
\text { Drylander alfalfa } \\
\text { Cicer milkvetch } \\
\text { Orenberg alfalfa }\end{array}$ & $\begin{array}{l}62 \mathrm{~b} \dagger \\
64 \mathrm{a} \\
63 \mathrm{a} \\
62 \mathrm{~b}\end{array}$ & $\begin{array}{l}66 a \\
65 a \\
65 a \\
64 b\end{array}$ & $\begin{array}{l}\text { NA } \\
\text { NA } \\
\text { NA } \\
\text { NA }\end{array}$ & $\begin{array}{l}66 a \\
66 a \\
66 a \\
65 b\end{array}$ & $\begin{array}{l}66 \mathrm{~b} \\
66 \mathrm{~b} \\
69 \mathrm{a} \\
67 \mathrm{~b}\end{array}$ & $\begin{array}{l}- \\
- \\
-\end{array}$ & $\begin{array}{r}72 \mathrm{a} \\
70 \mathrm{~b} \\
68 \mathrm{c}\end{array}$ & $\begin{array}{l}68 \ddagger \\
67 \\
67 \\
66\end{array}$ \\
\hline $\begin{array}{l}\text { Grasses } \\
\text { Reed canarygrass } \\
\text { Meadow bromegrass } \\
\text { Altai wildrye } \\
\text { Russian wildrye } \\
\text { Crested wheatgrass } \\
\text { Green needlegrass } \\
\text { Pubescent wheatgrass }\end{array}$ & $\begin{array}{l}64 a \\
61 b \\
64 a \\
65 a \\
55 d \\
58 c \\
54 d\end{array}$ & $\begin{array}{l}63 \mathrm{~b} \\
59 \mathrm{c} \\
60 \mathrm{c} \\
57 \mathrm{~d} \\
56 \mathrm{e} \\
57 \mathrm{~d} \\
57 \mathrm{~d}\end{array}$ & $\begin{array}{l}\text { NA } \\
\text { NA } \\
\text { NA } \\
\text { NA } \\
\text { NA } \\
\text { NA } \\
\text { NA }\end{array}$ & $\begin{array}{l}66 a \\
65 b \\
60 c \\
61 c \\
60 c \\
58 d \\
59 d\end{array}$ & $\begin{array}{l}67 \mathrm{~b} \\
66 \mathrm{~b} \\
64 \mathrm{c} \\
65 \mathrm{c} \\
61 \mathrm{e} \\
63 \mathrm{~d} \\
61 \mathrm{e}\end{array}$ & $\begin{array}{c}-\overline{b 2 b} \\
65 \mathrm{a} \\
63 \mathrm{~b} \\
64 \mathrm{a} \\
59 \mathrm{c} \\
63 \mathrm{~b}\end{array}$ & $\begin{array}{l}-\overline{65 d} \\
63 \mathrm{e} \\
57 \mathrm{i} \\
61 \mathrm{~g} \\
62 \mathrm{f} \\
59 \mathrm{~h}\end{array}$ & $\begin{array}{l}65 \\
63 \\
62 \\
61 \\
60 \\
60 \\
60\end{array}$ \\
\hline $\begin{array}{l}\text { Average } \\
\text { F test } \\
\text { SE }\end{array}$ & $\begin{array}{l}61 \\
* * \\
0.6\end{array}$ & $\begin{array}{l}61 \\
* * \\
0.5\end{array}$ & NA & $\begin{array}{l}63 \\
* * \\
0.4\end{array}$ & $\begin{array}{l}65 \\
\neq * \\
0.6\end{array}$ & $\begin{array}{l}63 \\
* * \\
0.7\end{array}$ & $\begin{array}{l}64 \\
* * \\
0.4\end{array}$ & \\
\hline
\end{tabular}

Treatment means followed by the same letter within a column are not significantly $(P=0.05)$ different from each other (Scott and Knott, 1974).

Average of only 4 yrs.

* Highly significant $(P<0.01)$ differences among species that year.

NA - Data not available.

the 3 alfalfas during the last 6 years did not differ significantly.

Other studies have shown that Russian wildrye produced only 50 to $60 \%$ as much forage as did crested wheatgrass when seeded in rows 15 to $30 \mathrm{~cm}$ apart (Clark and Heinrichs 1957; Stitt 1958; Whitman et al. 1961; Dubbs 1966, Dubbs 1975) or $46 \mathrm{~cm}$ apart (Seamands and Roehrkasse 1974). Leyshon et al. (1981) found that Russian wildrye produced 50,80 , and $110 \%$ as much forage, respectively, as crested wheatgrass when seeded in rows 30,60 , and $90 \mathrm{~cm}$ apart, respectively. However, our study indicated that Russian wildrye and crested wheatgrass produced nearly equal amounts of forage when seeded in rows $50 \mathrm{~cm}$ apart.

When seeded alone in rows $30 \mathrm{~cm}$ or less apart, alfalfa produced significantly more forage than either Fairway crested wheatgrass (Clark and Heinrichs 1957), standard crested wheatgrass (Whit- man et al. 1962, Dubbs 1975), or Russian wildrye (Dubbs 1975). However, the reporting investigators used Ladak alfalfa, which is branch rooted, and all 3 of the alfalfas we used were the creepingrooted type. Creeping-rooted types produce less forage than the branch-rooted types but persist longer under grazing (Heinrichs 1963).

Forage yields reported by others for green needlegrass have been erratic relative to crested wheatgrass yields. Green needlegrass produced more than (Clark and Heinrichs 1957), nearly the same as (Dubbs 1966), or significantly less than (Whitman et al. 1961, Stitt 1958) crested wheatgrass in studies conducted for 3 to 8 years.

Digestibility

The DMD of alfalfas and cicer milkvetch was highest and that of

Table 3. Crude protein (CP) concentration of grasses and legumes harvested at anthesis or at $10 \%$ bloom for 7 years near Sidney, Montana.

\begin{tabular}{|c|c|c|c|c|c|c|c|c|}
\hline \multirow[b]{2}{*}{ Species/cultivars } & \multicolumn{8}{|c|}{$\mathbf{C P}$} \\
\hline & 1975 & 1976 & 1977 & 1978 & 1979 & 1980 & 1981 & $\begin{array}{r}\text { Avg. } \\
1976-81\end{array}$ \\
\hline & \multicolumn{8}{|c|}{$-\%$} \\
\hline \multicolumn{9}{|l|}{ Legumes } \\
\hline Rambler alfalfa & $17 \mathrm{a} \dagger$ & $17 a$ & $19 a$ & $20 \mathrm{a}$ & $18 \mathrm{~b}$ & - & $23 a$ & 19 \\
\hline Cicer milkvetch & $18 \mathrm{a}$ & $17 a$ & $20 \mathrm{a}$ & $19 \mathrm{~b}$ & $21 \mathrm{a}$ & - & - & $19 \ddagger$ \\
\hline Orenberg alfalfa & $17 a$ & $17 \mathrm{a}$ & $20 \mathrm{a}$ & $20 \mathrm{a}$ & $18 \mathrm{~b}$ & - & $20 \mathrm{~b}$ & 19 \\
\hline Drylander alfalfa & $18 \mathrm{a}$ & $17 \mathrm{a}$ & $19 a$ & $19 b$ & $18 \mathrm{~b}$ & - & $22 \mathrm{a}$ & 19 \\
\hline \multicolumn{9}{|l|}{ Grasses } \\
\hline Reed canarygrass & $19 \mathrm{a}$ & $16 a$ & $19 a$ & $10 \mathrm{c}$ & $15 \mathrm{c}$ & - & - & 15 \\
\hline Altai wildrye & $16 a$ & $13 b$ & $15 \mathrm{~b}$ & $9 c$ & $10 e$ & $11 \mathrm{~b}$ & $12 \mathrm{c}$ & 12 \\
\hline Russian wildrye & $18 \mathrm{a}$ & $11 \mathbf{b}$ & $11 \mathrm{c}$ & $8 \mathrm{c}$ & 11d & $10 \mathrm{c}$ & 9d & 10 \\
\hline Green needlegrass & $17 a$ & $10 c$ & $13 \mathrm{c}$ & 7d & $12 \mathrm{~d}$ & $9 c$ & IIc & 10 \\
\hline Meadow bromegrass & $15 \mathrm{a}$ & $10 c$ & $12 \mathrm{c}$ & $7 d$ & $10 \mathrm{e}$ & $8 \mathrm{c}$ & 9d & 9 \\
\hline Crested wheatgrass & $10 \mathrm{~b}$ & $9 c$ & $8 d$ & $7 d$ & $8 f$ & $13 \mathbf{a}$ & $8 d$ & 9 \\
\hline Pubescent wheatgrass & $10 \mathrm{~b}$ & $7 \mathrm{c}$ & 9d & $7 d$ & 9f & $11 \mathrm{~b}$ & $8 d$ & 8 \\
\hline Average & 16 & 13 & 15 & 12 & 14 & 10 & 14 & \\
\hline F test & $* *$ & $* *$ & $* *$ & ** & $=*$ & $* *$ & $* *$ & \\
\hline SE & 1.1 & 0.7 & 0.9 & 0.4 & 0.5 & 0.5 & 0.4 & \\
\hline
\end{tabular}

$†$ Treatment means followed by the same letter within a column are not significantly $(P=0.05)$ different from each other (Scott and Knott, 1974).

tAverage of only 4 yrs.

* Highly significant $(P<0.01)$ differences among species that year. 
crested wheatgrass, green needlegrass, and pubescent wheatgrass was generally lowest (Table 2). The DMD of reed canarygrass forage was the highest among the grasses. No long-term data on DMD of major forage species harvested at anthesis in the northern Great Plains have been found in the literature. In a 2-year study, Lawrence and Knipfel (1981) found that the in vitro organic matter digestibility of Altai and Russian wildryes and of crested wheatgrass harvested in late June from irrigated land was in the same order as that found in this study.

The DMD of all species over the 6 years was inversely proportional with forage yield. As forage yield decreased by each 1,000 $\mathrm{kg} / \mathrm{ha}, \mathrm{DMD}$ increased by an average of $3,2.3,2.0$, and 1.5-1.8 percentage units for crested wheatgrass, Russian wildrye, legumes, and all other species, respectively. The drought in 1980 reduced the DMD of only meadow bromegrass below what the proportional reduction in forage yield would have increased it, but had no additional effects on the DMD of the other species over that caused by reduced forage yields. In contrast, Wilson (1983) found that drought decreased DMD but reported that the literature showed that drought had both positive and negative effects on DMD.

From 1976-1981 (excluding 1977), Drylander alfalfa, Altai wildrye, and Rambler alfalfa produced the largest average digestibleforage yields 1100,1090 , and $1020 \mathrm{~kg} /$ ha, respectively. The average digestible-forage yield of Orenberg alfalfa was lower than that of the other alfalfas. Reed canarygrass and meadow bromegrass produced the lowest average digestible-forage yield $(760$ and 520 $\mathrm{kg}$ / ha respectively) during this period because they produced the lowest forage yiclds.

\section{Crude Protein}

The CP concentration in the legume forage was nearly double that in the grasses (Table 3). Reed canarygrass contained the highest average $\mathrm{CP}$ of the grasses; crested and pubescent wheatgrasses, the lowest. The CP was highest in 1975 for all species because the previous summer fallowing had made extra $\mathrm{N}$ available to the plants. Previous studies have shown that alfalfa contains significantly more CP than grasses (Dubbs 1975), and that Russian wildrye contains more $\mathrm{CP}$ than do wheatgrasses or green needlegrass (Whitman et al. 1961; Dubbs 1966).

Legumes had a common regression for CP versus forage yield for all years, but grasses required a separate regression line for the first 2 or 3 years because $C P$ was about 5 units higher than during the next 4 years. The $C P$ concentration of all legumes decreased about 0.8 percentage units with every $1,000 \mathrm{~kg} /$ ha increase in forage yield when averaged over all years. During the last 4 years, the $\mathrm{CP}$ concentration of all grasses, excluding reed canarygrass, decreased about 1.25 percentage units with every $1,000 \mathrm{~kg} / \mathrm{ha}$ increase in forage yield.

The CP yield/ha for legumes was nearly double that for the grasses ( 280 versus $140 \mathrm{~kg} / \mathrm{ha}$ ) during the last 6 years, and the $\mathrm{CP}$ yield / ha for grasses was highest for Altai and Russian wildrye, 190 and $170 \mathrm{~kg} / \mathrm{ha}$, respectively. Green needlegrass, crested and pubescent wheatgrasses, reed canarygrass, and meadow bromegrass had the lowest average CP yield during the last 6 years of the study, 140 , $130,120,120$, and $110 \mathrm{~kg} / \mathrm{ha}$, respectively.

\section{Conclusions}

Forage quality was inversely proportional with forage yield. The DMD decreased between 1.5 and 2.3 percentage units for every $1,000 \mathrm{~kg} / \mathrm{ha}$ increase in forage yield except for crested wheatgrass, where DMD decreased about 3.0 percentage units per $1,000 \mathrm{~kg} / \mathrm{ha}$ increase in forage yield. Summer fallowing before seeding increased the CP concentration of the grasses about 5 percentage units during the first 2 or 3 years. The CP concentration of legumes and grasses decreased about 0.8 and 1.25 percentage units, respectively, for every $1,000 \mathrm{~kg} / \mathrm{ha}$ increase in forage yield.
Cicer milkvetch and reed canarygrass did not appear to be adapted for long-term dryland forage production in the northern Great Plains because they did not survive the 1980 drought. Alfalfas should be used for forage production in the northern Great Plains because of their high DMD and CP; however, they produced less forage than green needlegrass and the two wildryes during a drought. Altai wildrye appeared to be one of the most desirable grasses for the characteristics measured, and meadow bromegrass the least desirable. Pubescent and crested wheatgrass were nearly identical in forage yield and quality during the study, except that crested wheatgrass produced more forage during the drought.

\section{Literature Cited}

Black, A.L., and J.R. Wight. 1979. Range fertilization: Nitrogen and phosphorus uptake and recovery over time. J. Range Manage. 32:349-353.

Clark, K.W., and D.H. Heinrichs. 1957. Grass-legume mixture trials. Can. Dep. Agr. Bull.

Dewey, D.R., and C. Hsiao. 1983. A cytogenetic basis for transferring Russian wildrye from Elymus to Psathyrostachys. Crop Sci. 23:123-126.

Dubbs, A.L. 1966. Yield, crude protein, and palatability of dryland grasses in central Montana. Montana Agr. Exp. Sta. Bull. 604.

Dubbs, A.L. 1975. Performance of grasses, legumes and mixtures on dryland in central Montana as measured by species competition, yield, and quality. Montana Agr. Exp. Sta. Bull. 683.

Heinrichs, D.H. 1963. Creeping alfalfas. p. 317-337. In: A.G. Norman (ed.) Advances in Agronomy. Academic Press, New York.

Kilcher, M.R. 1980. Influence of test period and sequence of years on results with perennial forage crops in a semiarid region. Can. J. Plant Sci. 60:1191-1201.

Kilcher, M.R., and D.H. Heinrichs. 1974. Interpretive difficulties with erratic data from perennial forage crops grown in a semiarid region. Can. J. Plant Sci. 54:457-462.

Lawrence, T. 1978. An evaluation of thirty grass populations as forage crops for southwestern Saskatchewan. Can. J. Plant Sci. 58:107-115.

Lawrence, T., and J.E. Knipfel. 1981. Yield and digestibility of crested wheatgrass and Russian and Altai wild ryegrasses as influenced by $\mathbf{N}$ fertilization and date of first cutting. Can. J. Plant Sci. 61:609-618.

Leyshon, A.J., M.R. Kilcher, and J.D. McElgunn. 1981. Seeding rates and row spacings for three forage crops grown alone or in alternate grassalfalfa rows in southwestern Saskatchewan. Can. J. Plant Sci, 61:711-717.

NRC (Nutional Research Council; Subcommittee on Beef Cattle Nutrition). 1976. Nutrient requirements of beef cattle. Pub. 4. National Academy of Sciences-National Research Council, Washington, D.C.

Schuman, G.E., M.A. Stanley, and D. Knudsen. 1973. Automated total nitrogen analysis of soil and plant samples. Soil Sci. Soc. Am. Proc. 37:480-481.

Scott, A.J., and M. Knott. 1974. A cluster analysis method for grouping means in the analysis of variance. Biometrics 30:507-512.

Seamands, W.J., and G.P. Roehrkasse. 1974. Dryland grass variety trials in Wyoming 1964-1973. Wyoming Agr. Exp. Sta. Bull. B608.

Stitt, R.E. 1958. Factors affecting yield and quality of dryland grasses. Agron. J. 50:136-138.

Troelsen, J.E., and J.B. Campbell. 1969. The effect of maturity and leafiness on the intake and digestibility of alfalfas and grasses fed to sheep. $J$. Agr. Sci. (Camb.) 73:145-154.

White, L.M. 1979. Relationship between meteorological measurements and flowering of index species to flowering of 53 plant species. Agr. Meteorology 20:189-204.

White, L.M., and J.R. Wight. 1981. Seasonal dry matter yield and digestibility of seven grass specics, alfalfa, and cicer milkvetch in eastern Montana. Agron. J. 73:457-462.

Whitman, W.C., D.R. Peterson, and T.J. Conlon. 1961. Grass studies at Dickinson... Results of clipping trials with cool season grasses. North Dakota Farm Res. 22(2):9-14.

Whitman, W.C., D.R. Petersen, and T.J. Conlon. 1962. Grass studies at Dickinson ... Results of clipping trials with grasses and grass-alfalfa mixtures. North Dakota Farm Res. 22(3):4-13.

Wilson, J.R. 1983. Effects of water stress on herbage quality. Proc. XIV Int. Cong. p. $470-472$. 